\title{
Simulation and Analysis of Multilevel Inverter Fed Brushless DC Motor Drive
}

\author{
Mekala Rajesh, G.S.N.M. Venkatesh, G. Joga Rao
}

\begin{abstract}
In this paper the output of a five-level inverter-fed brushless DC motor drive is evaluated and described. Because of the many benefits of this topology, a cascaded $\mathrm{H}$-Bridge inverter topology was selected for the study. On the basis of the mathematical model of the brushless DC motor, the simulation model of the motor is developed. In MATLAB/SIMULINK, the whole model of the inverter-fed drive is simulated. The inverter output voltage, engine torque, back EMF, and harmonic analysis of the inverter voltage are all seen as waveforms. With a five-level inverter, the output voltage is of high quality. According to the simulation review, the efficiency of BLDC is strong when fed by a five-level inverter, Index Terms: Brush less DC motor, Inverter, Control, Modulation of Inverter.
\end{abstract}

Keywords: Performance of BLDC, Multilevel inverter, Electric Drive.

\section{INTRODUCTION}

A regular brush less direct current (BLDC) motors are fed from the pulse width modulated inverters with two levels in output voltage. The high dv/dt stress caused by the two-level AC voltage has an impact on the BLDC motor drive's output. Furthermore, the typical mode voltages produced contribute to motor drive issues. The design of the output voltage obtained by the inverter circuit must be modified to reduce the influence of the common mode voltage[2].This requires a modification in the topology of the inverter circuit. This is possible by employing a multilevel inverter instead of a conventional two level inverter to drive the

Day by day multilevel inverters are gaining the popularity in power industry. These inverters are employed in various applications, among which the motor drives is an important area in electrical engineering domain. The biggest advantage of multilevel inverter is the reduce voltage stress during the operation compared with the output voltage of the conventional two level inverters[10]. Reduced voltage stress in an important feature that is required for the BLDC motor. If the voltage levels are more than or equal to three in output voltage, then it is called multilevel inverter. It is possible to design the multilevel inverter for any power levels.

Manuscript published on July 30, 2021.

* Correspondence Author

Mr. M Rajesh*, Pursuing M.Tech (Power Electronics), Raghu Institute of Technology (Autonomous) Visakhapatnam (A.P.), India.

G.S.N.M. Venkatesh, Assistant Professor, Raghu Institute of Technology, Dhakamarri, Visakhapatnam (A.P), India.

Dr. G Joga Rao, Associate Professor, Department of Electronics and Electrical Engineering, Raghu Institute of Technology (Autonomous) Visakhapatnam. (A.P), India

(C) The Authors. Published by Blue Eyes Intelligence Engineering and CC BY-NC-ND license (http://creativecommons.org/licenses/by-nc$\underline{n d / 4.0 /)}$ BLDC motor for any application.

Manuscript received on May 23, 2021

Revised Manuscript received on July 22, 2021. Sciences Publication (BEIESP). This is an open access article under the

Multilevel inverters are classified into three groups. The diode clamped inverters, flying capacitor inverters, and cascaded H-Bridge multilevel inverters are three types of inverters. These three topologies are very popular in power industry. Even though they are very popular, every type of inverters has their own disadvantages. Therefore, it is always use choice to choose particular type of multilevel inverter depending on the application.

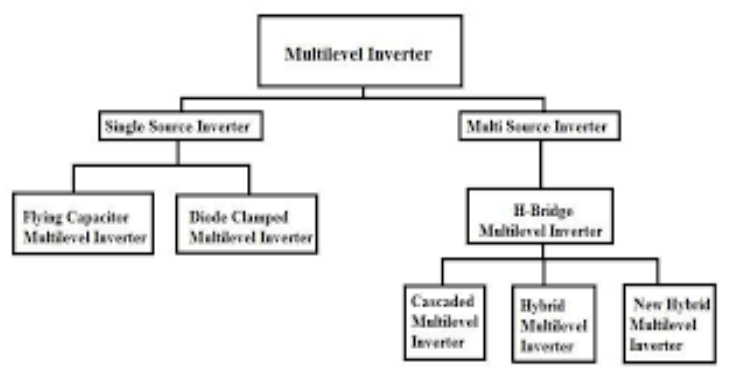

FIG 1 Classification of Multilevel Inverters.

Various types of multilevel inverters are shown in Fig 1. Out of three conventional inverters, the cascaded $\mathrm{H}$ bridge inverters are mostly preferred compared to others. Cascaded $\mathrm{H}$ bridge inverters require less number of components compared to other two types of inverters. The other reason to prefer the cascaded inverters is, these can be easily extendable to get any number of levels in output voltage [7]. The topology is simple and easy to implement. Hence, the cascaded $\mathrm{H}$ bridge inverters are mostly preferred compared to other two types.

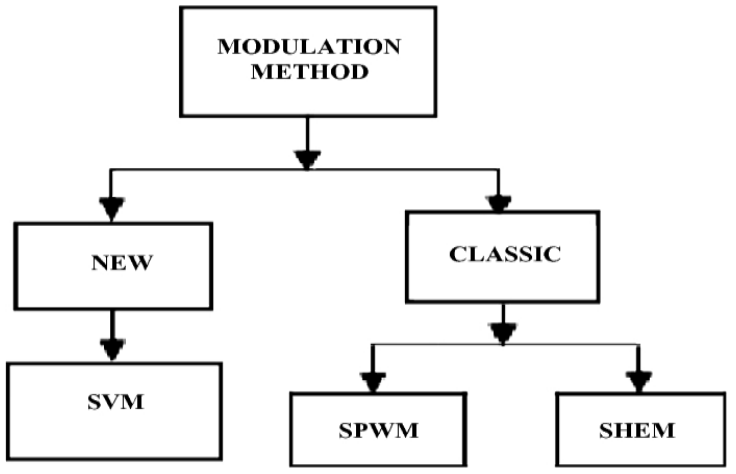

FIG 2 Classification of modulation methods.

The output voltage of the inverter is often affected by the modulation system used in the multilevel inverter. SPWM is an easy and efficient modulation approach that is ideal for cascaded multilevel inverters (SPWM). SPWM is a high frequency modulation technique.

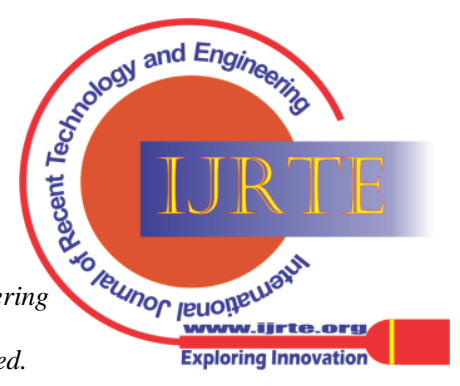


There are several modulation approaches, but due to its ease of execution, SPWM is preferred in many inverters. The Cascade $\mathrm{H}$ bridge inverters are modular in design. As a result, the SPWM is superior to all other methods.

This article employs a cascaded $\mathrm{H}$ bridge inverter topology with five steps. The BLDC motor is operated by the output voltage of the five-level cascaded $\mathrm{H}$ bridge inverter. The motor's output is calculated and contrasted to the performance of a traditional two-level inverter.

The rest of the paper is arranged accordingly. Section II describes how the five-level inverter works. Section III contains a model of the BLDC engine. Section IV presents the simulation performance of the BLDC motor push. The thesis appears in the final part of the document.

\section{FIVE LEVEL CASCADED H - BRIDGE INVERTER}

The cascaded $\mathrm{H}$ bridge inverter is made up of a series of $\mathrm{H}$ bridge cells that are cascaded. The number of $\mathrm{H}$ bridges needed is determined by the inverter's number of levels. Each $\mathrm{H}$ bridge cell is capable of producing three levels of production. There are three levels: optimistic, negative, and empty. Two $\mathrm{H}$ Bridge cells are expected to achieve five levels of output voltage [3].

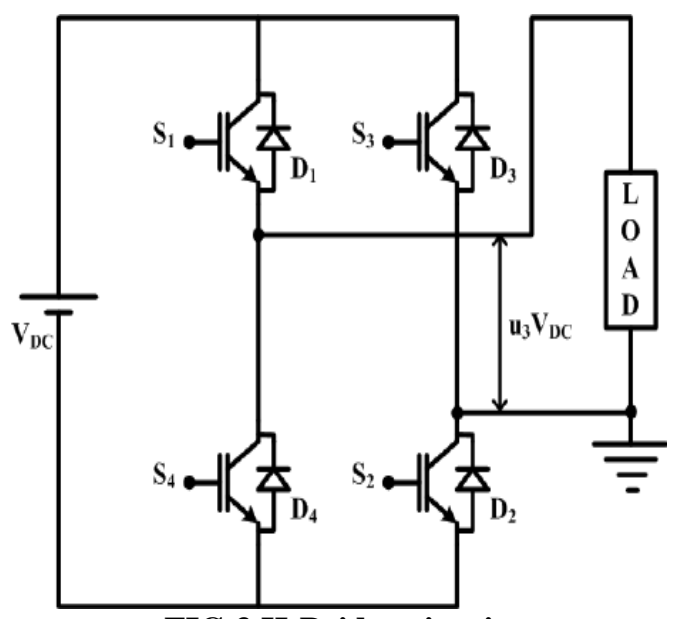

FIG 3 H-Bridge circuit.

The Fig 3 shows the $\mathrm{H}$ bridge circuit. This can generate three levels in output voltage waveform. The switching tables to generate three voltage levels are shown in Table 1, which is shown below.

TABLE I Switching states for three levels.

\begin{tabular}{|c|c|}
\hline Switches Turn ON & Voltage Level \\
\hline $\mathrm{S} 1, \mathrm{~S} 2$ & $\mathrm{Vdc} / 2$ \\
\hline $\mathrm{S} 3, \mathrm{~S} 4$ & $-\mathrm{Vdc} / 2$ \\
\hline $\mathrm{S} 2, \mathrm{~S} 4$ & 0 \\
\hline
\end{tabular}

The following Fig 4 shows the circuit of an $\mathrm{N}$ level cascaded $\mathrm{H}$ bridge inverter.

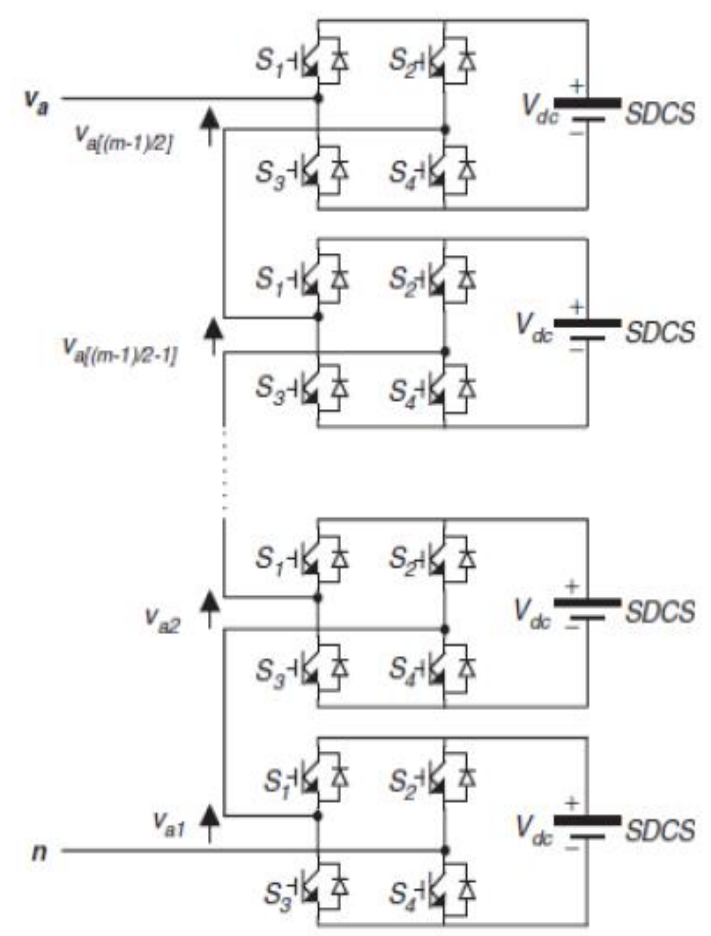

FIG 4 N Level H-Bridge circuit.

$\mathrm{N}$ is the total number of floors, where $\mathrm{S}$ is the number of $\mathrm{H}$ bridges. According to this relationship, a five-level inverter necessitates two $\mathrm{H}$-bridges, a seven-level inverter necessitates three $\mathrm{H}$-bridges, and so on.. In this work, a five level inverter is considered in the analysis. Further, the structure and the operation of the five level inverter along with its switching states is presented below.

\subsection{Five Level Inverter:}

The topology of the cascaded $\mathrm{H}$ bridge five level inverter is shown below. This circuit consists of two $\mathrm{H}-$ Bridges connected in cascaded mode.

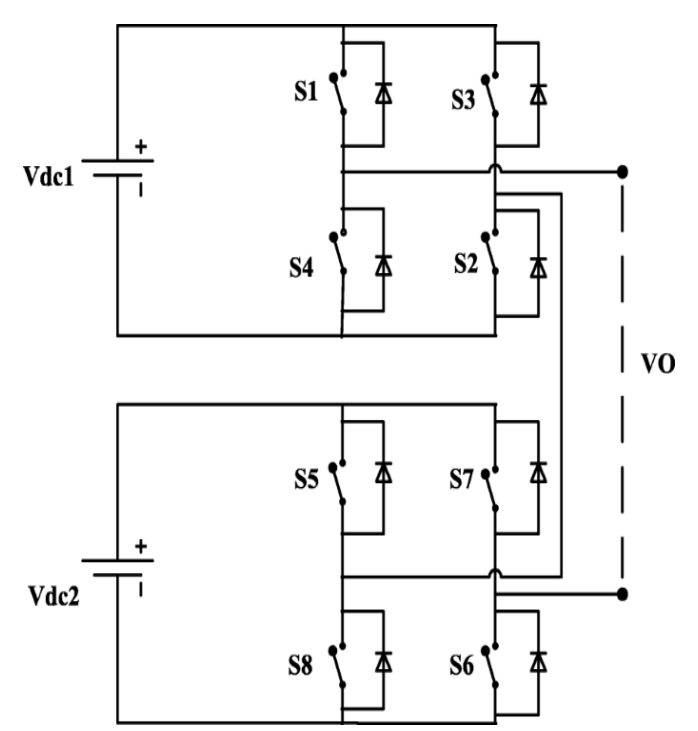

FIG 5 FIVE Level H-Bridge circuit. 
There are total eight switches, four switches per bridge in a five level inverter. In case of the cascaded H-bridge inverter, the overall voltage level is double that of DC sources. This type of inverters can be manufactured quickly.

TABLE II Switching states for five levels.

\begin{tabular}{|c|c|}
\hline Switches Turn ON & Voltage Level \\
\hline $\mathrm{S} 1, \mathrm{~S} 2, \mathrm{~S} 6, \mathrm{~S} 8$ & $\mathrm{Vdc} / 2$ \\
\hline $\mathrm{S} 1, \mathrm{~S} 2, \mathrm{~S} 5, \mathrm{~S} 6$ & $\mathrm{Vdc}$ \\
\hline $\mathrm{S} 2, \mathrm{~S} 4, \mathrm{~S} 6, \mathrm{~S} 8$ & 0 \\
\hline $\mathrm{S} 3, \mathrm{~S} 4, \mathrm{~S} 6, \mathrm{~S} 8$ & $-\mathrm{Vdc} / 2$ \\
\hline $\mathrm{S} 3, \mathrm{~S} 4, \mathrm{~S} 7, \mathrm{~S} 8$ & $-\mathrm{Vdc}$ \\
\hline
\end{tabular}

The above table represents the switching of various states in a five level inverters to produce various levels. Minimum four switches are required to produce each level in output voltage. The load can be either resistive, inductive, and/or it can be a motor. In this case the load is BLDC motor.

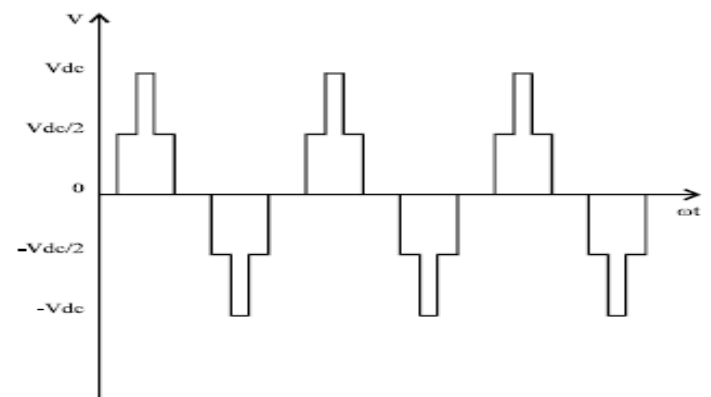

FIG 6 Five level inverter output voltage.

When the values of the DC sources are identical, the device is referred to as a symmetrical multilevel inverter. The model wave shape of the output voltage is depicted in the Fig above. A five-level output voltage waveform has two positive voltage levels, two negative voltage levels, and a zero voltage level..

\subsection{Modulation of Inverter:}

As stated in the introduction, sinusoidal pulse width modulation method is employed in present work. SPWM is a high frequency modulation method. It is made up of two waves: a modulating wave and a carrier wave. The pulses are produced and applied to the inverter switches based on the frequency of a carrier wave. The frequency values are determined by the modulation index of the inverter. (a)

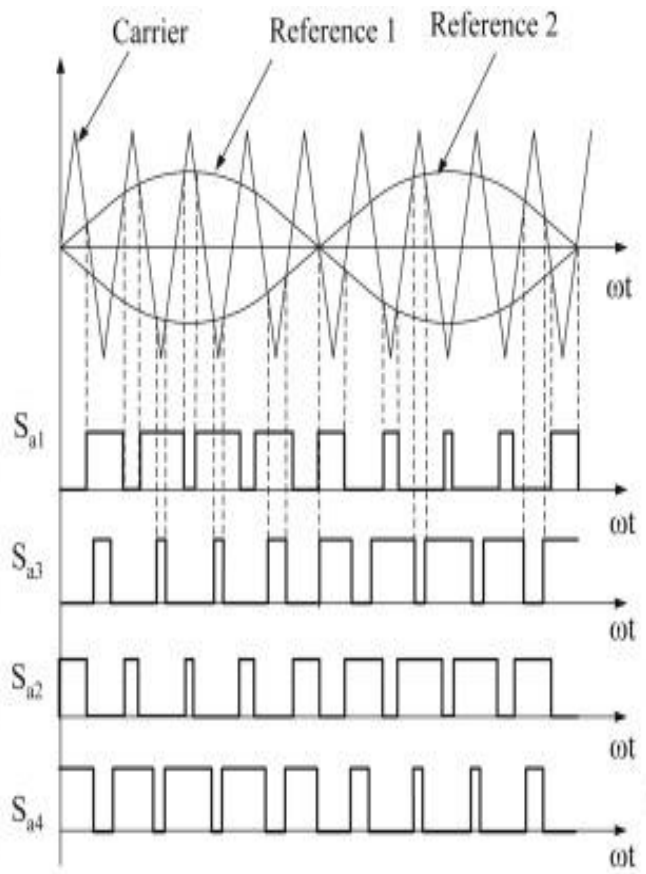

Fig 7 FIVE LEVEL INVERTER PWM.

The above Fig shows the methodology of generating the PWM pulses for a five level cascaded $\mathrm{H}$ bridge multilevel inverters using SPWM method.

\section{BLDC MODEL}

As opposed to other types of engines, BLDC has very low ohmic errors. But for a few differences, BLDC motors are close to synchronous motors. These motors come in a variety of configurations. To feel the direction of the rotor, this motor needs an inverter circuit. This is attributed to the lack of a brush and a commutator. The diagram below depicts the design of a BLDC engine.

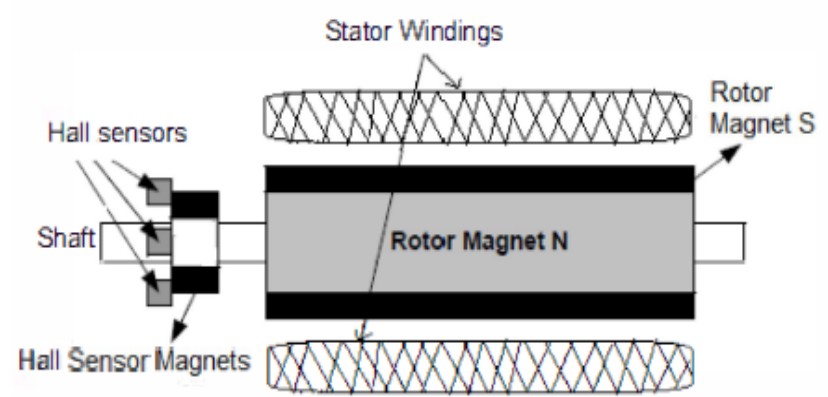

FIG 8 BLDC Motor.

BLDCs are employed in various applications in several industries. Following are the advantages of BLDC motors.

- Low noise.

- Fast dynamic response.

- Good torque.

- Long life.

- Good efficiency.

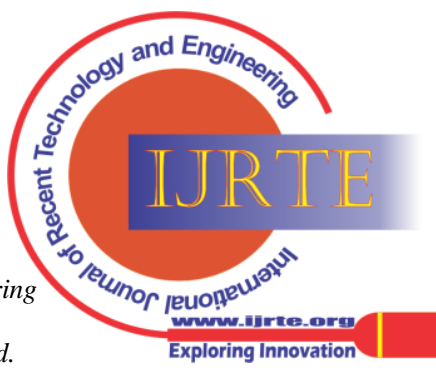


3.1 Mathematical Model of BLDC Motor:

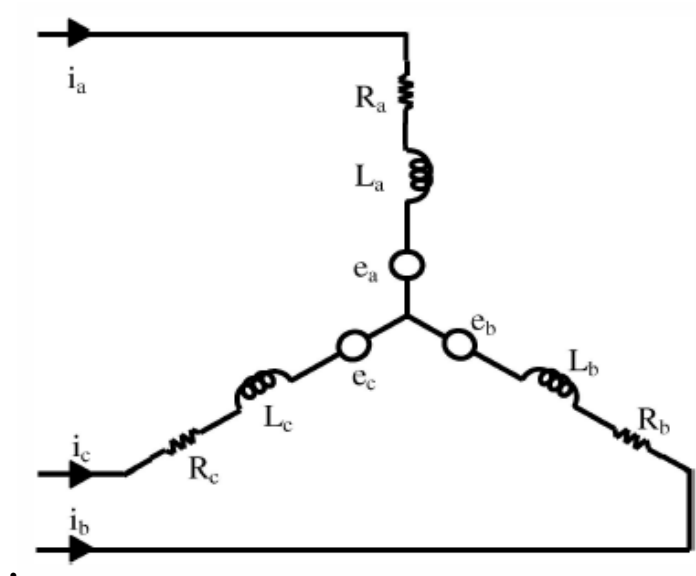

FIG 8 Equivalent Circuit BLDC Motor.

The BLDC's statistical concept is used to derive its mathematical model. Permanent magnets are installed in the rotors of BLDC motors. This motor may be driven by some kind of alternating current waveform, such as sinusoidal or square wave. Several assumptions are made during the creation of this BLDC motor mathematical model.

The mathematical model of the BLDC motor is expressed as

$$
\begin{aligned}
& V_{a}=R i_{a}+L \frac{d i_{a}}{d t}+e_{a} \\
& V_{b}=R i_{b}+L \frac{d i_{b}}{d t}+e_{b} \\
& V_{c}=R i_{c}+L \frac{d i_{c}}{d t}+e_{c}
\end{aligned}
$$

The above series of equations is known as the BLDC motor's mathematical model. The same model can also be represented in matrix form, as seen below.

$$
\left[\begin{array}{l}
V_{a} \\
V_{b} \\
V_{c}
\end{array}\right]=\left[\begin{array}{ccc}
R+p L & 0 & 0 \\
0 & R+p L & 0 \\
0 & 0 & R+p L
\end{array}\right]\left[\begin{array}{l}
i_{a} \\
i_{b} \\
i_{c}
\end{array}\right]+\left[\begin{array}{c}
e_{a} \\
e_{b} \\
e_{c}
\end{array}\right]
$$

In above mathematical model $\mathrm{V}$ is the voltage supplied, and $\mathrm{e}$ is the back EMF generated. The back EMF wave forms are shown in Fig below.

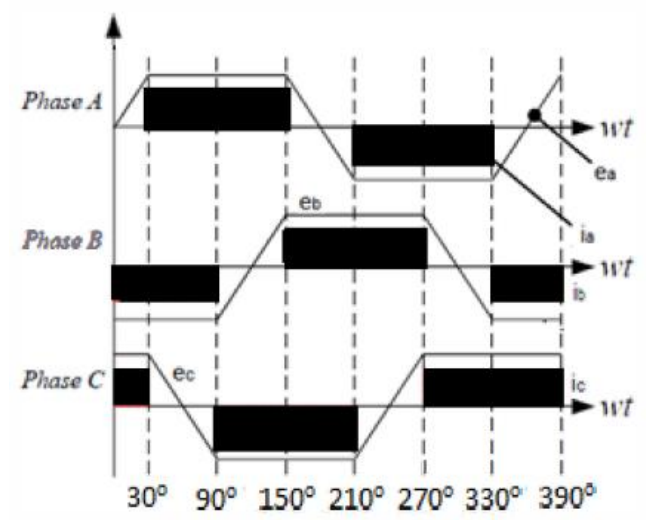

FIG 9 Back EMF of BLDC Motor.
Following are the equations for the back EMF in BLDC motor.

$$
\begin{aligned}
& e_{a}=k \cdot \omega \cdot f(\theta) \\
& e_{b}=k \cdot \omega \cdot f\left(\theta-\frac{2 \pi}{3}\right) \\
& e_{c}=k \cdot \omega \cdot f\left(\theta+\frac{2 \pi}{3}\right)
\end{aligned}
$$

The electromagnetic torque is

$$
\begin{aligned}
& T_{e}=\frac{i_{a} e_{a}+i_{b} e_{b}+i_{c} e_{c}}{\omega}= \\
& i_{a} \cdot K \cdot f(\theta)+i_{b} . K \cdot f\left(\theta-\frac{2 \pi}{3}\right)+i_{c} \cdot K \cdot f\left(\theta+\frac{2 \pi}{3}\right)
\end{aligned}
$$

The resultant torque is

$$
T_{e}-T_{L}=J \frac{d \omega}{d t}+B \omega
$$

The above expression is used in torque calculation.

\section{SIMULATION RESULTS}

The simulation results of a five-level cascaded $\mathrm{H}$ bridge inverter and the BLDC drive fed by the five-level cascaded $\mathrm{H}$ bridge inverter are discussed in this portion. Both simulations are performed in MATLAB/SIMULINK.

\subsection{Five Level Inverter Simulations:}

The below Fig shows the simulation circuit of a five level cascaded $\mathrm{H}$ bridge inverter with resistive load. In a three phase inverter, the similar two more phases are required to get three phase voltages.
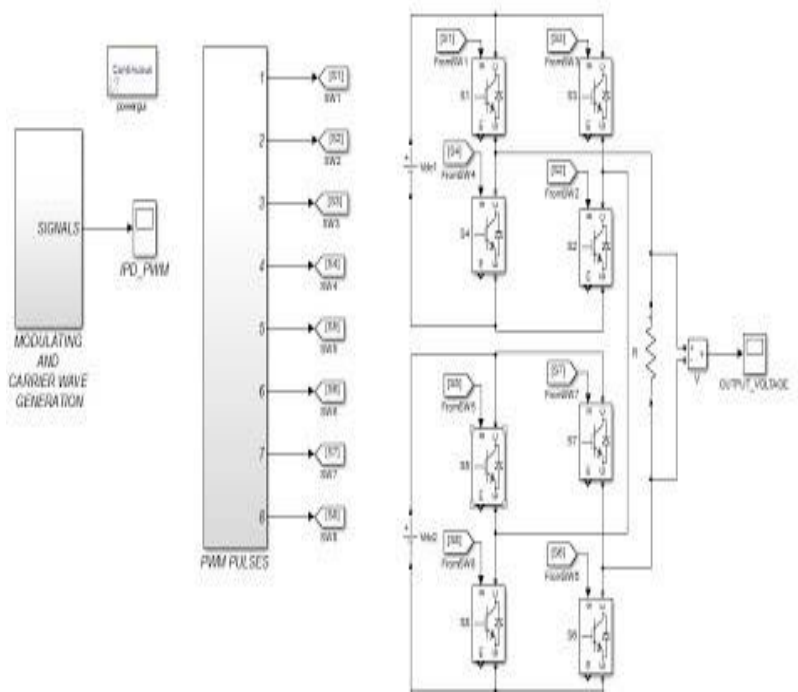

FIG 9 Simulation Circuit of a 5 Level Inverter.

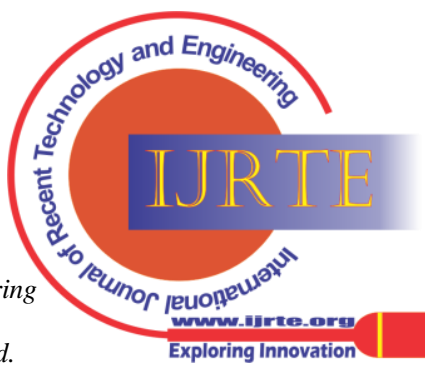




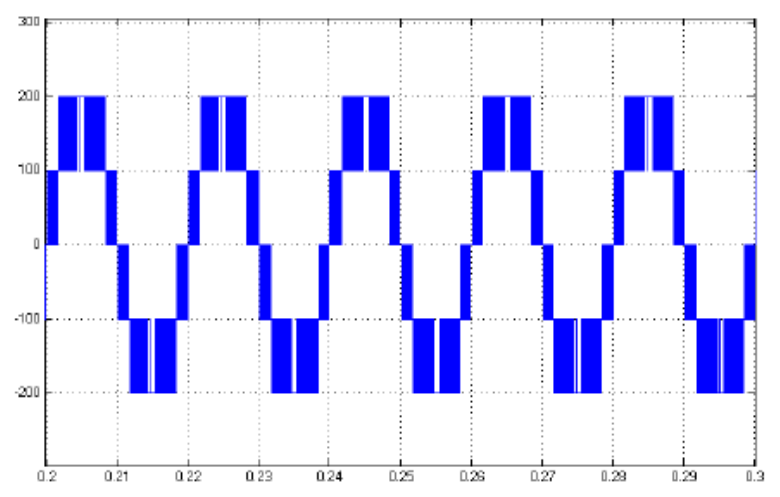

FIG 10 Output voltage of a 5 Level Inverter

The above Fig shows the output voltage obtained by a five level CHB inverter. The wave form consists of two positive levels, two negative levels, and a zero level.

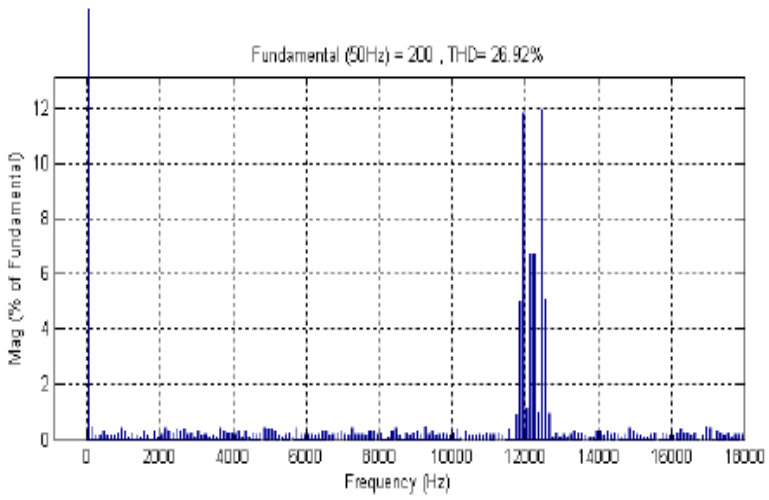

FIG 11 FFT of output voltage of a 5 Level Inverter.

The above Fig 11 shows the FFT spectrum of a output voltage obtained by five level CHB inverter. The THD value is $26.92 \%$. The below table give the number of components required for the $\mathrm{CHB}$ inverter.

TABLE III Inverter components.

\begin{tabular}{cc}
\hline & CHB Multilevel inverter \\
\hline Phase to neutral voltage levels & $\mathrm{P}_{\mathrm{nv}}$ \\
Line to line voltage levels & $\left(2 \mathrm{P}_{\mathrm{nv}}-1\right)$ \\
No. of switches per phase & $2\left(\mathrm{P}_{\mathrm{nv}}-1\right)$ \\
No. of power module per phase & $\left(\mathrm{P}_{\mathrm{nv}}-1\right) / 2$ \\
Output voltage THD & same \\
No. of isolated DC source per phase & $\left(\mathrm{P}_{\mathrm{nv}}-1\right) / 2$ \\
Modulation strategy & same \\
Power of each isolated Dc source & $2 \mathrm{P} / 3\left(\mathrm{P}_{\mathrm{nv}}-1\right)$ \\
\hline
\end{tabular}

\subsection{BLDC Drive Simulations:}

The block diagram of a inverter fed BLDC is shown in Fig below.

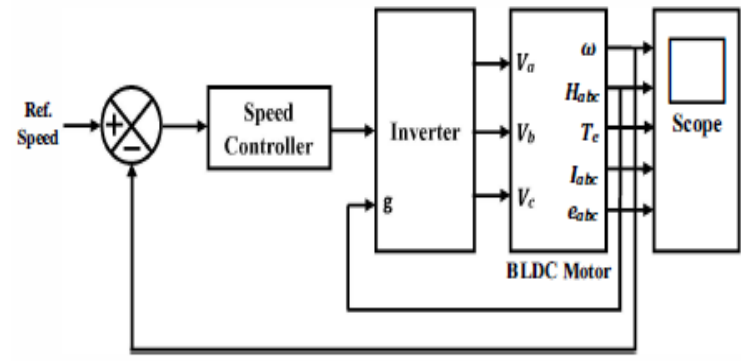

FIG 12 Schematic of BLDC drive.

The specifications of the BLDC motor considered in the analysis are shown in table below.

TABLE IV Motor Specifications.

\begin{tabular}{|c|c|}
\hline Motor parameters & Values \\
\hline No. of poles, & 4 \\
\hline Moment of inertia, $\mathrm{J}$ & $0.0002 \mathrm{Kg}-\mathrm{m}^{2}$ \\
\hline Stator Resistance, $\quad \mathrm{R}$ & $0.7 \Omega$ \\
\hline Stator Inductance, $\quad \mathrm{L}$ & $0.0272 \mathrm{H}$ \\
\hline Rated Speed, & $3000 \mathrm{rpm}$ \\
\hline Damping Constant, $\mathrm{B}$ & 0.2 \\
\hline Back EMF Constant, K & $0.513 \mathrm{volt} / \mathrm{rad} / \mathrm{sec}$ \\
\hline Load Torque, & $4 \mathrm{~N}-\mathrm{m}$ \\
\hline
\end{tabular}

The below Fig is the MATLAB simulation diagram of a CHB inverter fed three phase BLDC motor drive circuit.

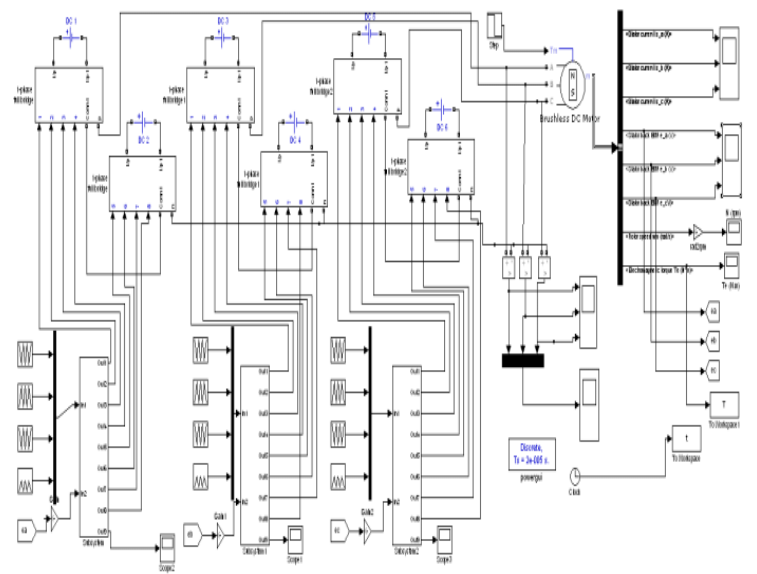

FIG 13 Simulation of BLDC drive.

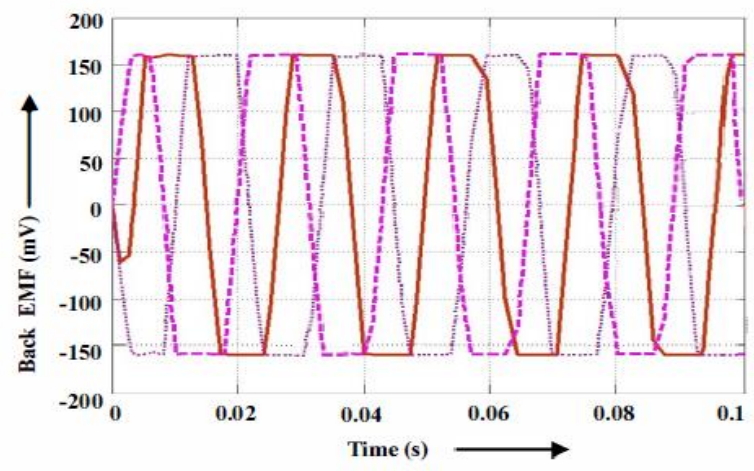

(a) Back EMF.

Published By:

Blue Eyes Intelligence Engineering and Sciences Publication

(C) Copyright: All rights reserved.

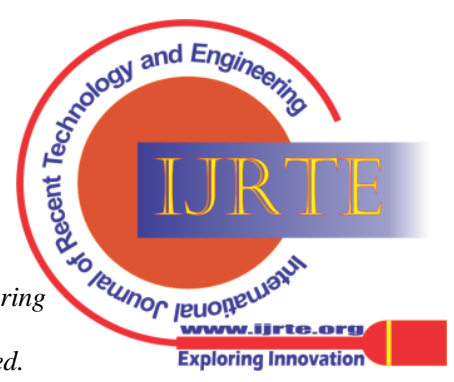




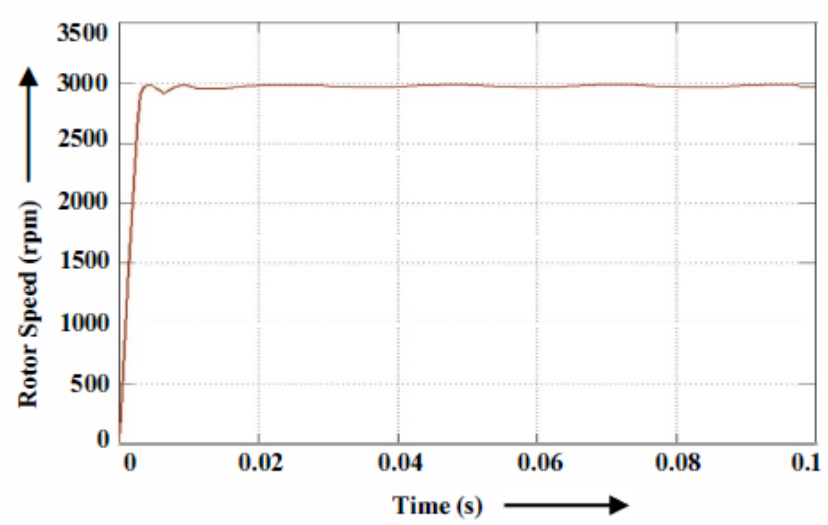

(b) Speed of motor

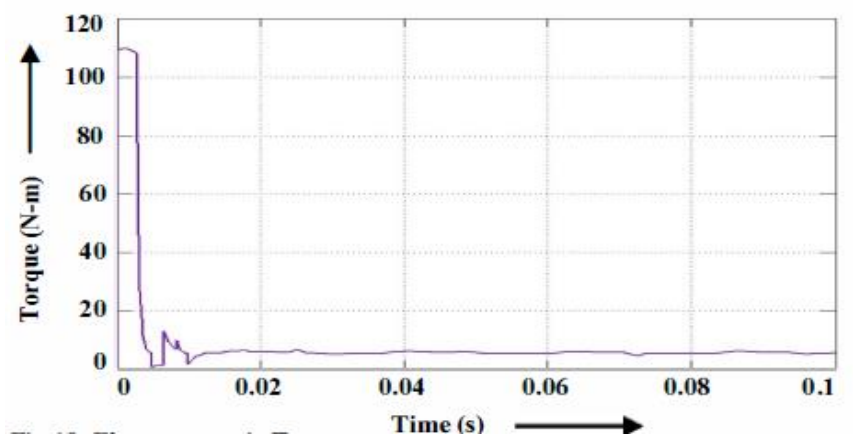

(c) Load torque.

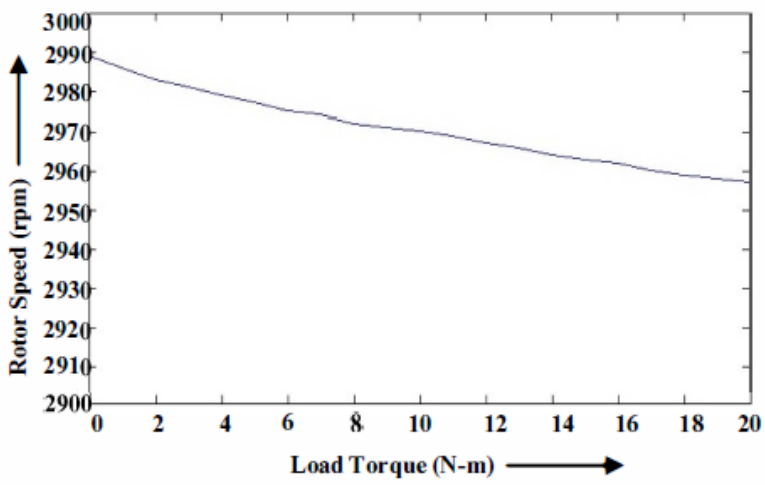

(d) Torque variation.

FIG 14 Various waveforms of BLDC drive.

\section{CONCLUSIONS}

The performance of the five level CHB inverter fed BLDC motor drive is analysed and the performance is found satisfactory. The torque wave form is smooth, and the back EMFs are very close to trapezoidal waveforms. The variation of the torque with load is also studied and the performance is good with the load variation. Over all, it can be concluded that the BLDC when fed by a multilevel inverter, the voltage stress becomes low, due to which the back EMFs are good, which results in satisfactory torque.

\section{REFERENCES}

1. Masmoudi, M., El Badsi, B., \& Masmoudi, A. (2013). DTC of B4inverter-fed BLDC motor drives with reduced torque ripple during sector-to-sector commutations. IEEE Transactions on Power Electronics, 29(9), 4855-4865.

2. Bist, V., \& Singh, B. (2014). PFC Cuk converter-fed BLDC motor drive. IEEE Transactions on Power Electronics, 30(2), 871-887.

3. Bist, V., \& Singh, B. (2013). An adjustable-speed PFC bridgeless buck-boost converter-fed BLDC motor drive. IEEE Transactions on Industrial Electronics, 61(6), 2665-2677.

4. Kumar, D., Gupta, R. A., \& Gupta, N. (2017, August). Minimization of current ripple and overshoot in four switch three-phase inverter fed BLDC motor using tracking anti-windup PI controller. In 2017 IEEE International Conference on Signal Processing, Informatics, Communication and Energy Systems (SPICES) (pp. 1-6). IEEE.

5. Darwin, S., Murugan, M., \& Chandran, J. G. (2015). A comparative investigation on DTC of B4-inverter-fed BLDC motor drives using PI and intelligent controllers. International Journal of Advanced Research in Electrical, Electronics and Instrumentation Engineering, 4(3), 1486-1494.

6. Crisbin, P., \& Sasikumar, M. (2016, March). Analysis of PFC cuk and PFC sepic converter based intelligent controller fed BLDC motor drive. In 2016 Second International Conference on Science Technology Engineering and Management (ICONSTEM) (pp. 304308). IEEE.

7. Ghosh, A., Santra, S. B., Maharana, M. K., \& Biswal, P. (2016, April). Torque ripple and efficiency optimization of a novel boost converter fed BLDC motor drive. In 2016 International Conference on Computation of Power, Energy Information and Commuincation (ICCPEIC) (pp. 344-349). IEEE.

8. Karthikeyan, B., Christa, S. J., \& Gnanavadivel, J. (2018, March) Modeling and Evaluation of Modified SEPIC Converter Fed BLDC Motor Drive. In 2018 Second International Conference on Electronics, Communication and Aerospace Technology (ICECA) (pp. 1900-1905). IEEE.

9. Singh, Bhim, and Vashist Bist. "Improved power quality bridgeless Cuk converter fed brushless DC motor drive for air conditioning system." IET Power Electronics 6, no. 5 (2013): 902-913.

10. Kavitha, M., \& Sivachidambaranathan, V. (2017, March). Power factor correction in fuzzy based brushless DC motor fed by bridgeless buck boost converter. In 2017 International Conference on Computation of Power, Energy Information and Commuincation (ICCPEIC) (pp. 549-553). IEEE.

\section{AUTHORS PROFILE}

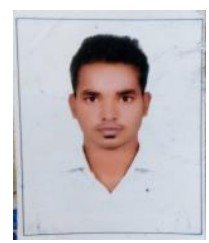

Mr. M Rajesh, is pursuing MTech (Power electronics) in Raghu Institute of Technology (Autonomous) Visakhapatnam. He obtained B.Tech (Electrical and Electronics Engineering)

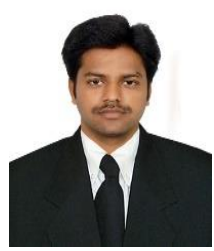

G. S. N. M. VENKATESH, Received M.Tech with specialization in Advanced Power systems from J.N.T. University, Kakinada, East Godavari (Dt), Andhra Pradesh, India. He is currently working as an Assistant professor at Raghu Institute of Technology, Dhakamarri, Visakhapatnam, A.P. His areas of interest are Power Systems, Power Electronics \& Industrial drives.

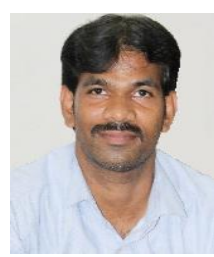

Dr. G Joga Rao, is working as an associate professor in the department of EEE, Raghu Institute of Technology (Autonomous) Visakhapatnam. He obtained B.Tech (Electrical Engineering) and MTech (Electrical Power Engineering) degree from J.N.T University, Hyderabad, in 2004 and 2007 respectively. He completed his doctoral program from S.R University, India in 2017. He has more than 15 years of teaching experience in various colleges and published more than 50 publications in various reputed international journals. His area of interest includes Energy Systems, Power Electronics and Renewable Energy Technologies. He is a life member of the Indian Society for Technical Education and Institute of Engineers IE.

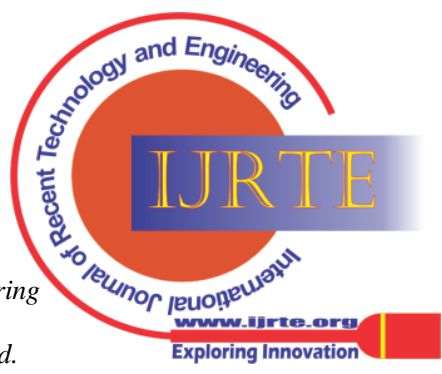

